REVIEW ARTICLE

\title{
EGFR チロシンキナーゼ阻害剤に対する耐性機構と克服
}

\author{
宗 淳一 1 豊岡伸 $-1 \cdot$ 上野 剛 $1 \cdot$ 三好新一郎 1
}

\section{Mechanisms and Overcome of Acquired Resistance to EGFR Tyrosine Kinase Inhibitors}

\author{
Junichi Soh1; Shinichi Toyooka1; Tsuyoshi Ueno1; Shinichiro Miyoshi1 \\ ${ }^{1}$ Department of Thoracic Surgery, Okayama University Hospital, Japan.
}

\begin{abstract}
Development of effective therapies for non-small-cell lung cancer (NSCLC) patients with epidermal growth factor receptor (EGFR) mutations, which account for approximately $40 \%$ of lung adenocarcinoma patients in Japan, is important to improve the clinical outcome of NSCLC. EGFR-mutant NSCLCs are sensitive to EGFR tyrosine kinase inhibitors (EGFR-TKIs), and elucidating the binding affinity of adenosine triphosphate (ATP) and EGFR-TKI to wild type or mutant EGFR helps our understanding of the mechanisms of resistance to EGFR-TKI. The mechanisms of acquired resistance to EGFR-TKIs are broadly classified into two categories: 1) secondly acquired EGFR mutations including T790M and 2) "oncogene kinase switch" such as MET gene amplification. To overcome the acquired resistance, it is essential to develop new drugs and therapeutic strategies. The heat shock protein 90 (Hsp90) inhibitors show anti-proliferative effect by inhibiting the stabilization of various client proteins such as mutant-EGFR, MET and AKT. The clinical trials of Hsp90 inhibitors are currentlyconducted, which is expected to show the efficacy on NSCLC patients with any kind of acquired resistance for EGFR-TKIs.
\end{abstract}

KEY WORDS — Acquired resistance, EGFR-TKI, T790M mutation, ATP, Hsp90 inhibitor

(JJLC. 2012;52:131-135)

Reprints: Shinichi Toyooka, Department of Thoracic Surgery, Okayama University Hospital, 2-5-1 Shikata-cho, Okayama, Okayama 700-8558, Japan (e-mail: toyooka@md.okayama-u.ac.jp).

要旨一一本邦の肺腺癌の約 $40 \%$ に認められる epidermal growth factor receptor (EGFR) 変異肺癌に対する有 効な治療法の開発は, 肺癌治療成績の向上において重要 である. EGFR 変異肺癌には EGFR チロシンキナーゼ阻 害剂 (EGFR-TKI) が高い感受性を示すが，遺伝子変異が もたらす EGFR 変異蛋白に対する EGFR-TKI とアデノ シン 3 リン酸 (ATP) の親和性の関係を知ることは感受 性・耐性の原因を理解する上で大切である。また, 薬殽 に対する獲得耐性の機構としては, T790M 変異に代表さ れる $E G F R$ 遺伝子の 2 次変異と $M E T$ 遺伝子増幅などの
キナーゼ乗り換え耐性の 2 つに大別される．EGFR-TKI 耐性肺癌の克服には，これら耐性化機構の理解に基づい た新規薬剤および治療法の開発が不可欠である.多くの 薬荗が開発されているが, heat shock protein 90(Hsp90) 阻害剤は, 変異型 $\mathrm{EGFR} \cdot \mathrm{MET} \cdot \mathrm{AKT}$ などの複数のク ライアント蛋白の安定化を阻害することで抗腫瘍効果を 示すため, 様々な機構を持つ EGFR-TKI 耐性肺癌への治 療効果が期待され, 現在臨床試験が行われている.

索引用語——獲得耐性, EGFR チロシンキナーゼ阻害 剂, T790M 変異, ATP, Hsp90 阻害剂
1 岡山大学病院呼吸器外科.

別刷請求先：豊岡伸一, 岡山大学病院呼吸器外科, $\bar{\top} 700-8558$

岡山市北区鹿田町 2-5-1 (e-mail: toyooka@md.okayama-u.ac.jp).
※第 51 回日本肺癌学会総会シンポジウム「肺癌の分子標的治 療一基礎から臨床へ」. 


\section{はじめに}

2004 年の epidermal growth factor receptor (EGFR) 遺伝子変異の発見は, EGFR 変異肺癌に対しゲフィチニ ブ，エルロチニブといった EGFR チロシンキナーゼ阻害 剂（EGFR-TKI）が著効することから脚光を浴びてい る. ${ }^{1,2} E G F R$ 変異肺癌は, 本邦の肺腺癌の約 $40 \%$ に認め られ, EGFR-TKI の抗腫瘍効果も報告されているため, その有効な治療法の開発は肺癌治療成績の向上において 重要である. 3 また, EGFR 変異肺癌に対し, プラチナダ ブレットとゲフィチニブを比較した，無増悪生存期間を エンドポイントとする 2 つ本邦における無作為化 III 相試験の結果が発表され, EGFR 変異肺癌に対し, ゲフィ チニブの有用性が証明された. 4,5 しかしながら, EGFRTKI による耐性の問題も早くから指摘されており, 6,7 EGFR-TKI 獲得耐性肺癌に対する治療法の開発も必要 である. 本稿では EGFR 変異と EGFR-TKI の感受性の機 構, 獲得耐性の機構, 獲得耐性肺癌に対する薬剤につい て概説する.

\section{$E G F R$ 変異に対するアデノシン 3 リン酸 (ATP) と EGFR チロシンキナーゼ}

EGFR は細胞膜に存在する膜貫通型チロシンキナーゼ 型受容体で,「増殖因子 (リガンド) が結合する細胞外領 域」「膜貫通領域」「チロシンキナーゼを含む細胞内領域」 の 3 つの領域から構成される. リガンドが結合すると EGFR は細胞膜上を移動し, EGFR 同士または他の EGFR ファミリー受容体（HER2 など）とホモ/へテロダ イマーを形成する。これにより細胞内領域にあるチロシ ンキナーゼ部位はアデノシン 3 リン酸 (ATP) と結合し, ATPを利用することで細胞内領域に存在するチロシン 残基をリン酸化する. チロシン残基のリン酸化は, PI3K/ Akt 経路, Ras/MAPK 経路, Jak/STAT 経路などを活性 し, 細胞増殖や抗アポトーシスのシグナルが伝達され る. 8

EGFR 遺伝子は 7 番染色体 $(7 \mathrm{p} 12)$ に存在し, エクソン 1〜16 は細胞外領域を, エクソン 17 は膜貫通領域を, エ クソン 18〜28 は細胞内領域をコードしている. 原発性肺 癌に認められる $E G F R$ 変異は, チロシンキナーゼの ATP 結合部位をコードしているエクソン 18～21 に生じ, リガ ンドの刺激によりチロシン残基を野生型と比較して長期 間リン酸化させ, 下流の細胞増殖・抗アポトーシスのシ グナルを増強させることで, 細胞の悪性化に関与してい る. ${ }^{1,2}$ 特に, エクソン 19 の欠失変異とエクソン 21 のコ ドン 858 のロイシンからアルギニンへの置換を来す変異 (L858R 変異) を有する肺癌の約 $80 \%$ の症例で, ゲフィ チニブ, エルロチニブなどの可逆型 EGFR-TKI が奏効す
るため, 非常に注目されている.9

EGFR-TKI は, ATP 結合部位に対して, ATP と競合 的・可逆的に結合することで, チロシン残基のリン酸化 および下流へのシグナル伝達を抑制して, 抗腫瘍効果を 発揮する.10 変異型 EGFR では, ATP への親和性が野生 型と比較して低下しており，かつ, EGFR-TKIへの親和 性が野生型 EGFRに比較して高くなっていることが報 告されている11 (Figure 1). L858R 変異型 EGFR であれ ば ATP への親和性は野性型 EGFR の 28 分の 1 であり, EGFR-TKI に対する親和性は約 17 倍高い結果であっ た. ${ }^{11}$ EGFR-TKI は元来変異型 EGFRに特異的にデザ インされたものではないが, 前述のように変異型 EGFR は野生型 EGFR に比べて ATPへの親和性が低下し, EGFR-TKI への親和性が増加しているため, 高い感受性 を示すと考えられている。

\section{EGFR-TKI への耐性化機構}

EGFR-TKI への耐性の機構は, 2 つの機構に大別され る. 1) EGFR 遺伝子 2 次変異による耐性化と, 2) キナー ゼ乗り換え耐性（oncogene kinase switch）である. 12

\section{1. $E G F R$ 遺伝子の 2 次変異獲得による耐性化}

$E G F R$ 変異の中でエクソン 20 の挿入変異, コドン 790 のスレオニンからメチオニンへの点変異 $(\mathrm{T} 790 \mathrm{M})$, コド ン 761 のアルギン酸からチロシンへの点変異 （D761Y）などが EGFR-TKI 耐性化に関与する EGFR 遺 伝子 2 次変異として知られている. 3 中でも T790M 変 異は, EGFR-TKIに耐性が生じた EGFR 変異症例の約 $50 \%$ に認められ，2次変異または治療前からのマイナー クローン由来の変異と考えられている. $67,13 \mathrm{~T} 790 \mathrm{M}$ 変 異による耐性化機構として, T790M 変異により ATP 結合部位が構造的変化を生じて EGFR-TKI の結合が阻 害されること,さらに T790M/L858R 変異型 EGFR では ATP の親和性が L858R 単独変異型 EGFR より高くな ること（Figure 1）により，T790M 変異はEGFR-TKI への耐性を示すと考えられている。 これらの耐性化機構 を克服するために, ATP に不可逆的に結合して下流への シグナル伝達を阻害する新規 EGFR-TKI が開発され, 臨 床試験が行われている（Table 1).

\section{2. キナーゼ乗り換え耐性 (oncogene kinase switch)}

EGFR-TKI に耐性が生じた EGFR 変異症例の約 $20 \%$ に, MET 遺伝子増幅が認められる. 14 また, その他の耐 性化機構としてインスリン様増殖因子 1 受容体（IGF1R）遺伝子の活性化も報告されている.15 これらの耐性 化機構は, 同受容体のチロシンキナーゼが活性化される ことにより, EGFR-TKI の存在下でも細胞増殖や分化の シグナル伝達が促進される, 言わば,「キナーゼ乗り換え (oncogene kinase switch) 」が生じることによると考えら 
a)

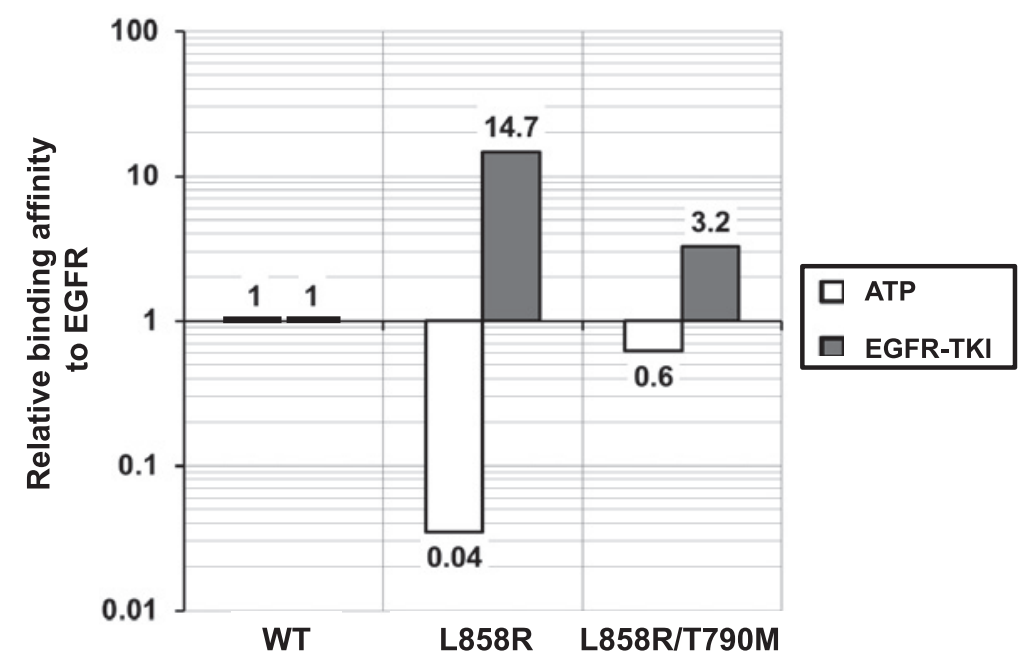

b)
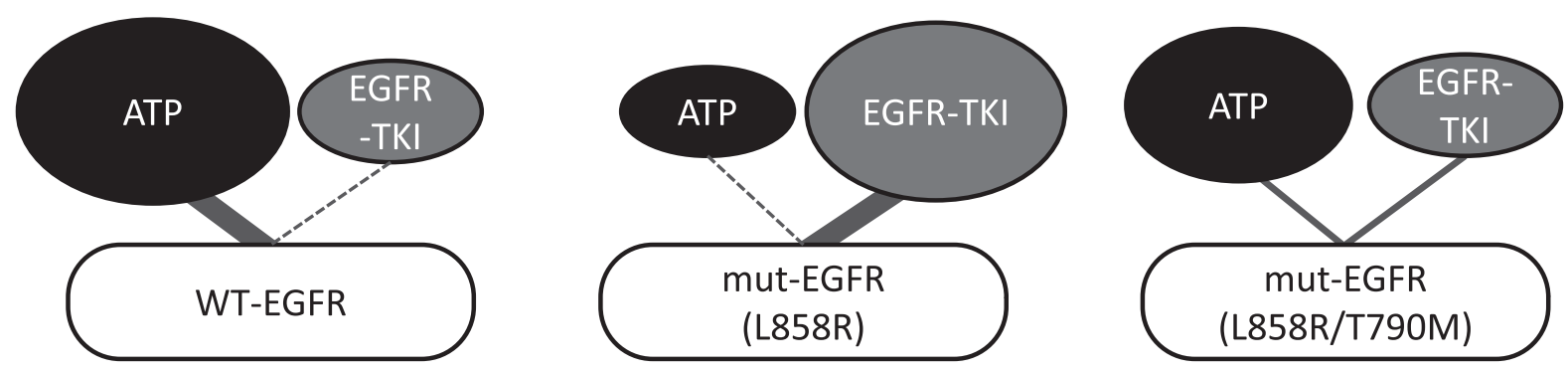

Figure 1. Binding affinity of ATP and EGFR-TKI to EGFR. a) Relative binding affinities of ATP and EGFR-TKI to EGFRs are shown (modified from ref 10). WT, wild type; L858R, EGFR exon 21 L858R mutation; T790M, EGFR exon 20 T790M mutation. b) Schema of competitive relationship between ATP and EGFR-TKI to wild type or mutant EGFR.

れる. ${ }^{12}$ MET 阻害剤や IGF-1R 阻害剤は, これら受容体 チロシンキナーゼ活性を阻害することが可能であるが, EGFR-TKI 耐性症例ではキナーゼ乗り換え後も変異 EGFR による下流のシグナル伝達は残存しているため, これら受容体阻害剤と EGFR-TKI の同時投与により抗 腫瘍効果を示すことが報告されている.14,15 また海外で は現在 MET, VEGFR2, RET の受容体キナーゼ阻害剂 であるXL184 と EGFR-TKIのコンビネーション治療に ついての臨床試験が進められている（NCT00596648） (Table 1).なお, 治療前からの MET 遺伝子増幅を持った マイナークローンの存在が報告されている. 16

その他の耐性化機構として, 近年 Sequist らにより, EGFR-TKI 獲得耐性肺癌の病理組織学的検討により約 $14 \%$ の症例で組織型が腺癌から小細胞肺癌となったこ とが報告された. 17 興味深いことに, これらの獲得耐性 肺癌は小細胞肺癌の化学療法に対して感受性を示すこと もわかっている。 また, 一部の症例では, epithelial-tomesenchymal transition が生じていることもわかってお り, EGFR-TKI 耐性化のメカニズムの 1 つとして, 表現
型の変化が関連していることが示唆されている.

\section{EGFR-TKI 耐性肺癌に対する治療}

ゲフィチニブ, エルロチニブなどの EGFR-TKI に対す る耐性化を克服することは肺癌治療成績向上の重要な課 題である. 前述の 2 つの耐性化機構を踏まえた新規治療 戦略が現在検討されている.

EGFR 遺伝子 2 次変異獲得による耐性化に対する治療 法として, 不可逆型 EGFR-TKI が検討されている. 中で も BIBW2992 は EGFR, HER2 に対する阻害剂であり, 18 T790M 変異によるゲフィチニブ, エルロチニブ耐性肺癌 にも効果を有することが報告されており, 現在, 臨床試 験が行われている (Table 1).

PF-02341066 やXL184 な゙の MET 阻害剤と EGFRTKI の併用療法も現在臨床試験で検討されている（Table 1). これらの併用療法は, キナーゼ乗り換え型の獲得 耐性機構, 特に MET 増幅による耐性化肺癌に対して有 効であると推測される.

さらに最近では heat shock protein 90 (Hsp90) に対す 
Table 1. Clinical Trials for NSCLC Patients with Acquired Resistance to EGFR-TKI

\begin{tabular}{|c|c|c|c|c|c|}
\hline Compound & Type of TKI & $\begin{array}{l}\text { ClinicalTrials.gov } \\
\text { identifier }\end{array}$ & Population of interest & Phase & Status \\
\hline BIBW2992 & $\begin{array}{l}\text { Irreversible EGFR/ } \\
\text { ErbB inhibitor }\end{array}$ & NCT00711594 & $\begin{array}{l}\text { Advanced NSCLC with failure } \\
\text { chemotherapy and EGFR-TKIs }\end{array}$ & II & Ongoing \\
\hline $\begin{array}{l}\text { PF-02341066 \& } \\
\text { PF-00299804 }\end{array}$ & $\begin{array}{l}\text { MET inhibitor \& irreversible } \\
\text { EGFR/ErbB2/ErbB3 inhibitor }\end{array}$ & NCT01121575 & $\begin{array}{l}\text { Advanced NSCLC with acquired } \\
\text { resistance to EGFR-TKIs }\end{array}$ & I & Ongoing \\
\hline XL184 & $\begin{array}{l}\text { VEGFR2/MET/RET inhibitor } \\
\text { (with or without EGFR-TKI) }\end{array}$ & NCT00596648 & NSCLC IIIb/IV, PD with erlotinib & $\mathrm{I} / \mathrm{II}$ & Ongoing \\
\hline Dasatinib & $\begin{array}{l}\text { BCR/ABL, Src, c-Kit, } \\
\text { Eph inhibitor }\end{array}$ & NCT00570401 & $\begin{array}{l}\text { Lung adenocarcinomas with } \\
\text { acquired resistance to EGFR-TKIs }\end{array}$ & II & Ongoing \\
\hline AUY922 & Hsp90 inhibitor & NCT01259089 & $\begin{array}{l}\text { Lung adenocarcinomas with } \\
\text { acquired resistance to EGFR-TKIs }\end{array}$ & $\mathrm{I} / \mathrm{II}$ & Ongoing \\
\hline
\end{tabular}

All data were queried from ClinicalTrials.gov (http://clinicaltrials.gov/).

る阻害剤が注目されている. Hsp90 は癌化に関与する蛋 白群のシャペロン蛋白である。 クライアント蛋白には癌 のシグナル伝達に関連する蛋白が多数含まれ, Hsp90 はその安定化に寄与している. T790M 変異を含む EGFR 変異蛋白, MET，その下流にある AKT などは, Hsp90 のクライアント蛋白であるため, Hsp90 阻害により, そ れらの安定化が失われ，肺癌において抗腫瘍効果を示す ことが報告されている. ${ }^{19,20} \mathrm{Hsp} 90$ 阻害剤として, geldanamycin (GM) の誘導体である 17 allylamino17 demethoxygeldanamycin (17-AAG ) や 17 dimethylaminoethylamino-17-demethoxygeldanamycin (17-DMAG)が知られる. 特に，17-DMAG は経口投与可 能な薬剤であり，17-DMAGが T790M変異を含む EGFR-TKI 耐性化肺癌に対して, in vitro, in vivoにおい て抗腫瘍効果を示すことが報告されている. ${ }^{19,21}$ 前述の ように, これら Hsp90 阻害剤は, EGFR 遺伝子の 2 次変 異を獲得した耐性肺癌にも, MET 遺伝子増幅などキナー ゼ乗り換え型耐性肺癌にも有用であるため, EGFR-TKI 耐性肺癌に対する治療薬としての可能性が検討されてい る.しかしながら，これらの Hsp90 阻害剤は臨床試験で その有効性・安全性を証明できず, 臨床応用には至って いない. そこで我々は治療効果と毒性を改善した新しい Hsp90 阻害剂 NVP-AUY922 について in vitroの検討を 行い, 17-DMAGより低い薬物濃度で T790M 変異を含む $E G F R$ 変異細胞株およびその他の多くの肺癌細胞株に対 して，高い抗腫瘍効果を示すことを見出している. 22 現 在, EGFR-TKI 耐性肺癌などに対して海外では臨床試験 が行われており (Table 1), 新規肺癌治療薬となりうるか 今後に注目したい.

\section{おわりに}

EGFR-TKI への耐性化は, 2 次性 EGFR 変異や $M E T$ 遺伝子増幅などのキナーゼ乗り換えにより生じる。 これ ら耐性化機構は, キナーゼのリン酸化のキープレーヤー
である ATP の結合能が変化すること, または異なるキ ナーゼにスイッチすることにより生じている。これら耐 性化機構を詳細に理解することは, EGFR-TKI 耐性肺癌 に対する治療戦略を考える上で非常に有用である。今後 のさらなる知見の集積により，新たな治療戦略の確立を 急ぐ必要がある。

本論文内容に関連する著者の利益相反：豊岡伸一〔講演料〕ア ストラゼネカ (株), 〔寄付金〕アストラゼネカ（株）

\section{REFERENCES}

1. Paez JG, Jänne PA, Lee JC, Tracy S, Greulich H, Gabriel $\mathrm{S}$, et al. EGFR mutations in lung cancer: correlation with clinical response to gefitinib therapy. Science. 2004;304: 1497-1500.

2. Lynch TJ, Bell DW, Sordella R, Gurubhagavatula S, Okimoto RA, Brannigan BW, et al. Activating mutations in the epidermal growth factor receptor underlying responsiveness of non-small-cell lung cancer to gefitinib. $N$ Engl J Med. 2004;350:2129-2139.

3. Tokumo M, Toyooka S, Kiura K, Shigematsu H, Tomii K, Aoe $\mathrm{M}$, et al. The relationship between epidermal growth factor receptor mutations and clinicopathologic features in non-small cell lung cancers. Clin Cancer Res. 2005;11:1167-1173.

4. Mitsudomi T, Morita S, Yatabe Y, Negoro S, Okamoto I, Tsurutani J, et al. Gefitinib versus cisplatin plus docetaxel in patients with non-small-cell lung cancer harbouring mutations of the epidermal growth factor receptor (WJTOG 3405): an open label, randomised phase 3 trial. Lancet Oncol. 2010;11:121-128.

5. Maemondo M, Inoue A, Kobayashi K, Sugawara S, Oizumi S, Isobe H, et al. Gefitinib or chemotherapy for non-small-cell lung cancer with mutated EGFR. $N$ Engl $J$ Med. 2010;362:2380-2388.

6. Kobayashi S, Boggon TJ, Dayaram T, Jänne PA, Kocher $\mathrm{O}$, Meyerson M, et al. EGFR mutation and resistance of non-small-cell lung cancer to gefitinib. $N$ Engl J Med. 2005; 352:786-792.

7. Pao W, Miller VA, Politi KA, Riely GJ, Somwar R, 
Zakowski MF, et al. Acquired resistance of lung adenocarcinomas to gefitinib or erlotinib is associated with a second mutation in the EGFR kinase domain. PLoS Med. 2005;2:e73.

8. Yarden Y, Sliwkowski MX. Untangling the ErbB signalling network. Nat Rev Mol Cell Biol. 2001;2:127-137.

9. Toyooka S, Takano T, Kosaka T, Hotta K, Matsuo K, Ichihara S, et al. Epidermal growth factor receptor mutation, but not sex and smoking, is independently associated with favorable prognosis of gefitinib-treated patients with lung adenocarcinoma. Cancer Sci. 2008;99:303308.

10. Wakeling AE, Guy SP, Woodburn JR, Ashton SE, Curry BJ, Barker AJ, et al. ZD1839 (Iressa): an orally active inhibitor of epidermal growth factor signaling with potential for cancer therapy. Cancer Res. 2002;62:5749-5754.

11. Eck MJ, Yun CH. Structural and mechanistic underpinnings of the differential drug sensitivity of EGFR mutations in non-small cell lung cancer. Biochim Biophys Acta. 2010;1804:559-566.

12. Nguyen KS, Kobayashi S, Costa DB. Acquired resistance to epidermal growth factor receptor tyrosine kinase inhibitors in non-small-cell lung cancers dependent on the epidermal growth factor receptor pathway. Clin Lung Cancer. 2009;10:281-289.

13. Inukai M, Toyooka S, Ito S, Asano H, Ichihara S, Soh J, et al. Presence of epidermal growth factor receptor gene T790M mutation as a minor clone in non-small cell lung cancer. Cancer Res. 2006;66:7854-7858.

14. Engelman JA, Zejnullahu K, Mitsudomi T, Song Y, Hyland C, Park JO, et al. MET amplification leads to gefitinib resistance in lung cancer by activating ERBB3 signaling. Science. 2007;316:1039-1043.

15. Guix M, Faber AC, Wang SE, Olivares MG, Song Y, Qu
$\mathrm{S}$, et al. Acquired resistance to EGFR tyrosine kinase inhibitors in cancer cells is mediated by loss of IGFbinding proteins. J Clin Invest. 2008;118:2609-2619.

16. Turke AB, Zejnullahu K, Wu YL, Song Y, Dias-Santagata D, Lifshits E, et al. Preexistence and clonal selection of MET amplification in EGFR mutant NSCLC. Cancer Cell. 2010;17:77-88.

17. Sequist LV, Waltman BA, Dias-Santagata D, Digumarthy S, Turke AB, Fidias P, et al. Genotypic and histological evolution of lung cancers acquiring resistance to EGFR inhibitors. Sci Transl Med. 2011;3:75ra26.

18. Li D, Ambrogio L, Shimamura T, Kubo S, Takahashi M, Chirieac LR, et al. BIBW 2992, an irreversible EGFR/ HER2 inhibitor highly effective in preclinical lung cancer models. Oncogene. 2008;27:4702-4711.

19. Shimamura T, Li D, Ji H, Haringsma HJ, Liniker E, Borgman CL, et al. Hsp90 inhibition suppresses mutant EGFR-T790M signaling and overcomes kinase inhibitor resistance. Cancer Res. 2008;68:5827-5838.

20. Sawai A, Chandarlapaty S, Greulich H, Gonen M, Ye Q, Arteaga CL, et al. Inhibition of Hsp90 down-regulates mutant epidermal growth factor receptor (EGFR) expression and sensitizes EGFR mutant tumors to paclitaxel. Cancer Res. 2008;68:589-596.

21. Kobayashi N, Toyooka S, Soh J, Yamamoto H, Dote H, Kawasaki K, et al. The anti-proliferative effect of heat shock protein 90 inhibitor, 17-DMAG, on non-small-cell lung cancers being resistant to EGFR tyrosine kinase inhibitor. Lung Cancer. 2012;75:161-166.

22. Ueno T, Tsukuda K, Toyooka S, Ando M, Takaoka M, Soh J, et al. Strong anti-tumor effect of NVP-AUY922, a novel Hsp90 inhibitor, on non-small cell lung cancer. Lung Cancer. 2012;76:26-31. 